25. Ужамецкая Е.А., Саксонов С.В. Некоторые итоги классификации растительных сообществ каменистых степей Жигулевских гор // Самарская Лука на пороге третьего тысячелетия: Мат-лы к докладу «Состояние природного и культурного наследия Самарской Луки». Тольятти: ИЭВБ РАН, 1999. С. 103-105.

26. Спрыгин И.И. Отчет о работе Л.М. Черепнина / сост. Л.А. Новикова // Фиторазнообразие Восточной Европы. 2013, VII: 2. С. 4-27.

27. Ястребова Н.А., Плаксина Т.И. Значение работы Л.М. Черепнина в изучении флоры и растительности Жигулей // Социально-экологические проблемы Самарской Луки. Куйбышев, 1990. С. 103-108.

28. Семенова-Тянь-Шанская А.М. Материалы к распределению сосновых лесов Приволжья // Труды Ботанического института им. В.Л. Комарова Академии Наук СССР. Серия III, выпуск 11. Ленинград, 1957. C. $309-338$

29. Кузьмичов А.И. Растительность каменистой степи в Жигулях // Украинский ботанический журнал. 1965. № 6. С. 106-107.

30. Тимофеев В.Е., Евдокимов Л.А., Матвеев В.И., Симакова Н.С. Опыт эколого-географического анализа флоры Самарской Луки // Флора и растительность Среднего Поволжья. Ульяновск: УГПИ, 1979. С. 43-49.

31. Задульская О.А. Опыт флороценотического исследования лесных опушек на территории Самарской Луки // Морфология и динамика растительного по- крова: науч. тр. Куйбышевского пед. ин-та. 1977. Т. 207. Вып. 6. С. 93-97.

32. Задульская О.А. Флора и растительность лесных опушек Самарской Луки // Социально-экологические проблемы Самарской Луки. Куйбышев, 1990. С. 92-94.

33. Ильина Н.С. Флора и растительность овражнобалочных систем южной части Самарской Луки // Социально-экологические проблемы Самарской Луки. Куйбышев, 1990. С. 81-85.

34. Бирюкова Е.Г., Ильина Н.С., Устинова А.А. Территориальные единицы растительного покрова Самарской Луки, пути их рационального использования и охраны // Проблемы рационального использования и охраны природного комплекса Самарской Луки. Куйбышев, 1983. С. 55-56.

35. Зеленая книга Самарской области: редкие и охраняемые растительные сообщества / под ред. Г.С. Розенберга и С.В. Саксонова. Самара: Самар. НЦ PAH, 2006. $201 \mathrm{c}$

36. Кудинов К.А. Жигулевский государственный заповедник. Куйбышев: Кн. изд-во, 1982. 48 с.

37. Кудинов К.А. Жигулевский заповедник. Тольятти, 2007. 134 с.

38. Сенатор С.А., Саксонов С.В. Средне-Волжский биосферный резерват: раритетный флористический комплекс / под ред. чл.-корр. РАН Г.С. Розенберга. Тольятти: Кассандра, 2010. 251 с.

\title{
HISTORY STUDY OF STEPPE VEGETATION IN THE MIDDLE-VOLGA COMPLEX BIOSPHERE RESERVE
}

(C) 2016

S.E. Gorlov, postgraduate student of the Laboratory of Problems of Phytodiversity Institute of Ecology of the Volga River Basin of Russian Academy of Sciences, Togliatti (Russia)

Abstract. Middle-Volga complex biosphere reserve is a specially-protected natural area in Samara region. The reserve was established in 2006 on the basis of Zhiguli reserve named after I. Sprygina and National Park «Samarskaya Luka» and became the first integrated biosphere reserve in Russia. The main purpose of the reserve is to ensure the conservation of Zhiguli landscapes and forest-steppe complexes of Middle Volga region, the organization of environmental monitoring and the development of careful environmental management system. The most valuable for research are fragments preserved in the reserve steppe areas, found only in small outlier unplowed areas in the southern and south-western part of Samarskaya Luka, in the Zhiguli and Sengileevskaya mountains. These are the remains of the steppe vegetation that once covered much of the plateau reserve. Although currently they are only small areas they cover all types of steppes in Samara region: meadow (north) steppe, present or feather-fescue (south), as well as special versions of steppe - shrubs, rocky and sandy. The uniqueness of the reserve nature, biodiversity, a large number of rare, endemic and relict species and communities could not but attract the attention of botanists from various periods. We consider the most important works from the point of view of studying the steppe vegetation.

Keywords: history of research; biodiversity; steppe vegetation; rocky steppes; geobotanic; Zhiguli mountains; Middle-Volga biosphere reserve; Samarskaya Luka; biodiversity conservation; reserve management and studies.

\section{УДК 57.04}

\section{ВОЗДЕЙСТВИЕ ХИМИЧЕСКИХ ВЕЩЕСТВ (ФОРМАЛЬДЕГИД И ТОЛУОЛ) НА ПОЧВЕННЫЕ МИКРООРГАНИЗМЫ ЧЕРНОЗЁМА ВЫЩЕЛОЧЕННОГО}

(C) 2016

Н.А. Ильина, доктор биологических наук, профессор кафедры географии и экологии T.В. Фуфаева, аспирант кафедры географии и экологии

Н.А. Казакова, кандидат биологических наук, старший преподаватель кафедры географии и экологии

Н.М. Касаткина, кандидат биологических наук, доцент кафедры географии и экологии

Е.А. Вилкова, кандидат биологических наук, доцент кафедры географии и экологии Ульяновский государственный педагогический университет имени И.Н. Ульянова, Ульяновск (Россия)

Аннотащия. В статье проведена оценка состояния почвенного покрова, связанная с загрязнением ее отходами химического производства и потребления. Представлены данные о влиянии формальдегида и толуола на 
численность актиномицетов, гетеротрофных бактерий и плесневых грибов, так как эти группы микроорганизмов обеспечивают самоочищающую способность почвы и участвуют в почвообразовательных процессах.

В данной работе были использованы микробиологические и физико-химические методы исследований. Исследование изменений видового состава некоторых групп почвенных микроорганизмов чернозема выщелоченного, под влиянием формальдегида и толуола показало, что этот фактор вызывает изменения в комплексе почвенных микроорганизмов. Данный фактор выражается в снижении видового богатства и разнообразия и увеличении доли толерантных к загрязнению микроорганизмов.

Данные исследования направлены на изучение ряда микроорганизмов, которые обеспечивают самоочищающую способность почвы и участвуют в почвообразовании. Полученные результаты показывают характер влияния различных доз формальдегида и толуола на состав и функционирование комплекса микроорганизмов почвы, а также вскрывают механизм воздействия химических веществ (формальдегиды и толуола) на почвенную микробиоту, связанный с ее устойчивостью и проявлением токсикоза почвы.

Ключевые слова: почва; чернозем выщелоченный; почвообразовательный процесс; формальдегид; толуол; гетеротрофные бактерии; актиномицеты; плесневые грибы; почвенные микроорганизмы; ксенобиотики; видовое богатство; самоочищающая способность; почвообразование; почвенная микробиота; токсикоз почвы; биохимическое значение.

Почва - одно из богатств, которыми располагает человек. Поэтому для человека важно изучение почвы как источника нашего пищевого благосостояния. Вместе с тем проявляется тенденция к уменьшению площадей плодородных земель вследствие ветровой и водной эрозии, а также загрязнения почвенного покрова человеком химическими веществами и отходами химических производств [2; 3].

Почвенный покров выполняет важные функции: биологического поглотителя, разрушителя и нейтрализатора загрязнений различного рода. Если данное звено биосферы будет разрушено, то сложившееся функционирование биосферы необратимо нарушится [4]. В связи с этим чрезвычайно важно изучение глобального биохимического значения почвенного покрова, его современного состояния и изменения под влиянием антропогенной деятельности человека, так как важнейшим значением почв является аккумулирование органического вещества, различных химических элементов, энергии. Охрана почв от загрязнений является наиболее важной задачей человека, так как любые вредные соединения и вещества, находящиеся в почве, рано или поздно попадают в организм человека $[5 ; 6]$.

Проблема оценки состояния почвенного покрова, связанная с загрязнением ее отходами химического производства и потребления, выбросами от стационарных и передвижных источников, применения агрохимикатов, является весьма актуальной [1].

В данной работе были использованы микробиологические и физико-химические методы исследований. Отбор почвы проводили в соответствии с ГОСТ 28168-89 [7].

Формальдегид определяли согласно методике СанПиН 42-128-4433-87 [8].

Определение толуола проводили в соответствии с методическими указаниями (определение массовых долей бензола и толуола в пробах почвы) [9; 10].

Статистическую обработку данных проводили с помощью встроенного статистического пакета Excel (MSOffice 2007). Повторность всех экспериментов трехкратная.

Исследования проб загрязненных почв направлены на изучение влияния химических веществ (формальдегид и толуол) на численность актиномицетов, гетеротрофных бактерий и плесневых грибов, так как эти группы микроорганизмов обеспечивают само- очищающую способность почвы и участвуют в почвообразовательных процессах.

Численность почвенных микроорганизмов, содержащей различные концентрации загрязнителя, определяли методом последовательных разведений почвенной суспензии на 5 и 30 сутки [11].

Плесневые грибы выявляли поверхностным методом, высевая 0,1 мл почвенной суспензии из разведения 10-2 на агаризованную среду Чапека-Докса. Актиномицеты выделяли так же, как и грибы, поверхностным методом, высевая 0,1 мл из разведения 10-3 на среду Красильникова № 1 [12]. Гетеротрофные бактерии выявляли глубинным методом посева 1 мл суспензии из разведения 10-5 на ГРМ-агар. Культивирование посевов осуществляли в термостате при 25 0С в течение 2 суток при выделении гетеротрофных, 5-7 суток при выделении актиномицетов и плесневых грибов. После инкубации посевов проводили количественный учет выросших колоний и определяли КОЕ в 1 г почвы. Динамику численности микроорганизмов в почве с ксенобиотиком отражали в процентах по отношению к контролю.

После 4 (с формальдегидом) и 8 (с толуолом) пассажей соответственно, в новую питательную среду из культуральной жидкости с накопительной культурой производили высев на чашки Петри с элективной твердой агаризованной средой М9 + формальдегид (толуол) и отбирали изолированные колонии.

Определение систематического положения отобранных штаммов бактерий проводится в соответствии с определителем бактерий Берги [13; 14; 15] по настоящее время.

При взаимодействии формальдегида с плесневыми грибами отмечено стимулирующее действие максимальных концентраций загрязнителя. При внесении 100 и 1000 доз ПДК увеличивалось количество плесневых грибов на 10-30\%, а в почве, содержащей 10 дозу ПДК, в первые дни численность грибов уменьшилась. На 30 сутки было отмечено снижение содержания грибов во всех пробах почвы с формальдегидом, особенно выделялись грибы из родов Mucor и Penicillium. Вероятнее всего, образующиеся продукты разложения обладали сильным токсическим действием на плесневые грибы.

Еще большее токсическое действие, особенно в первые дни контакта оказывал толуол на плесневые грибы, так как их содержание в пробах почвы снизи- 
лось на 30-80\%. Однако при дальнейших наблюдениях численность плесневых грибов не только восстанавливалась, но даже превысила контрольные показатели. При этом восстановление численности происходило в основном у родов Mucor и Penicillium. В пробе, содержащей 1000 доз ПДК, численность восстанавливалась с меньшей интенсивностью.

Анализ динамики численности актиномицетов, после внесения различных доз формальдегида показал ингибирующее действие на их размножение. На протяжении всех 30 суток отмечено непрерывное снижение количества актиномицетов в пробах с формальдегидом. К 30 дню наблюдалось уменьшение до 97\% численности актиномицетов во всех пробах почвы. Таким образом, действие формальдегида выражается в негативном действии на их размножение.

Совершенно иную динамику изменения численности наблюдали у актиномицетов, так как в первые дни контакта с толуолом их количество оставалось на исходном уровне, но к 30 дню произошло нарастание численности в условиях внесения всех трех доз ПДК $(10,100$ и 1000 доз ПДК). При этом интенсивное накопление актиномицетов наблюдалось при внесении повышенных доз ПДК.

Установлено, также, что на протяжении 30 суток происходило увеличение содержания гетеротрофных бактерий после внесения в нее доз формальдегида. Так в течение 30 суток наблюдали увеличение содержания гетеротрофных бактерий в почве. Внесение в почву концентрации 10 ПДК не сразу отразилось на размножение бактерий. В почве с максимальными дозами (100 и 1000 мг/кг) уже на пятые сутки количество бактерий на 10-45\% превышало контрольные значения, так к 30 дню численность гетеротрофов во всех пробах почвы увеличилась до 147-154\%.

Микробиологическими исследованиями проб почвы в различные интервалы времени установлено, что при внесении в почву толуола стимулировало рост, и размножение гетеротрофных бактерий в пробах почвы с ксенобиотиком на 5 сутки увеличивалась в 3-5 раз по сравнению с контролем, при этом выявлена зависимость размножения бактерий от дозы препарата.

Особенно высокое содержание микробов - 480\% было зафиксировано в почве, содержащей максимальную концентрацию в 1000 доз ПДК, что соответствовало 300 мг/кг. Количественные показатели бактерий в пробах почвы, содержащей 10 и 100 ПДК толуола, соответствующие 3 и 30 мг/кг, численно совпадали и составляли $345 \%$ от контроля. К 30 дню содержание микробов в почве несколько снижалось, но, тем не менее, оставалось довольно высоким, это дает основание полагать, что толуол способствовал активному размножению гетеротрофных бактерий.

После 4 пассажа на новую питательную среду из культуральной жидкости с накопительной культурой производили высев на чашки Петри с элективной твердой агаризованной средой М9 + формальдегид и отбирали изолированные колонии. Вследствие чего, удалось получить 2 изолята, которые устойчивы к формальдегиду в концентрации 50 мг/л. Они были исследованы на способность к деструкции в условиях непрерывного культивирования в аэробных условиях на минеральной среде М9. Выделенные 2 штамма бактерий были обозначены под шифрами Фд 1 и Фд 2
- это тонкие грамотрицательные палочки, которые на агаре Хоттингера с $\mathrm{pH} 7,6$ через 24 часа инкубации при температуре плюс $280 \mathrm{C}$ вырастают матовые, бугристые, с фестончатым краем колонии, дающие цветочный запах.

Так как формалин является раствором формальдегида, то выделенные штаммы деструкторы формальдегида (Фд 1 и Фд 2) использовали для ремедиации земель, загрязненных формалином.

Результаты исследования показывают, что после 48 часов инкубирования штаммы Фд 1 и Фд 2 разрушают 10 мг/л и 15 мг/л формальдегида. Изменение концентрации формальдегида при росте штаммов деструкторов Фд 1 и Фд 2 показано на рисунке 1.

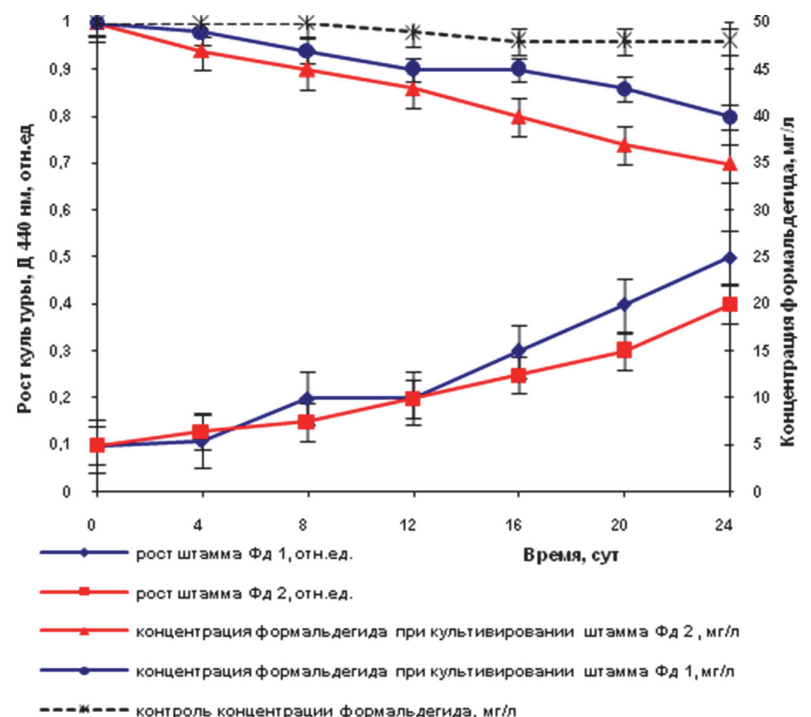

Рисунок 1 - Изменение концентрации формальдегида при росте штаммов деструкторов Фд 1 и Фд 2

После 8 пассажей в новую питательную среду из культуральной жидкости с накопительной культурой производили высев на чашки Петри с элективной твердой агаризованной средой М9 + толуол и отбирали изолированные колонии. Таким образом удалось получить 6 изолятов, устойчивых к толуолу в концентрации 150 мг/л. Они были исследованы на способность к деструкции в условиях непрерывного культивирования в аэробных условиях на минеральной среде М9. Выделенные 6 штаммов бактерий были обозначены под шифрами Тл 1, Тл 2, Тл 3, Тл 4, Тл 5 и Тл 6. При микроскопическом изучении данных видов бактерий установлено, что это мелкие грамотрицательные палочки бактерий, образующие на агаре мелкие, блестящие, гладкие, с однородной структурой, мягкой консистенцией, светлые выпуклые колонии с ровным краем.

Определение систематического положения отобранных штаммов проводится в соответствии с определителем бактерий Берги [13; 14; 15] по настоящее время. Анализ результатов, приведенных на рисунке 2 , показывает, что в течение 4 суток произошло снижение концентрации толуола на $50 \%$, затем рост культуры прекращался, в связи, с чем для эффективной работы консорциума необходимо проведение оптимизации условий биодеградации толуола $[16 ; 17 ; 18]$.

Исследование изменений видового состава некоторых групп почвенных микроорганизмов чернозема выщелоченного, под влиянием формальдегида и то- 
луола показало, что этот фактор вызывает изменения в комплексе почвенных микроорганизмов. Данный фактор выражается в снижении видового богатства и разнообразия и увеличении доли толерантных к загрязнению микроорганизмов.

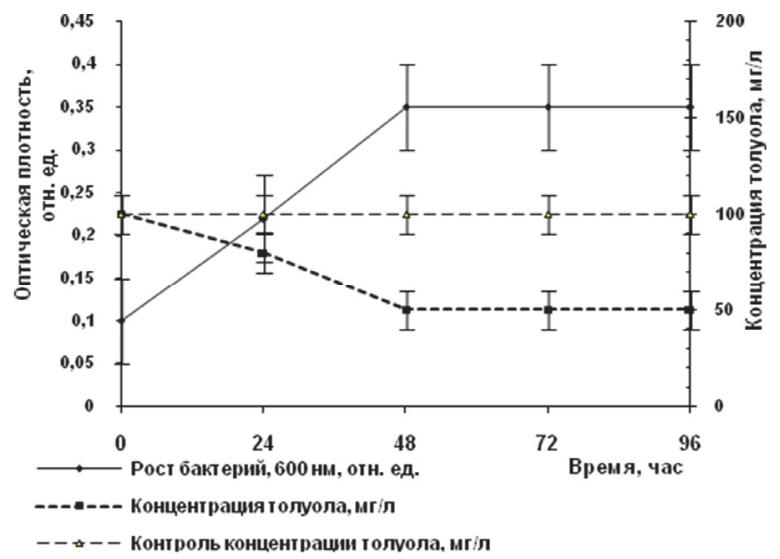

Рисунок 2 - Деградация толуол при концентрации 100 мг/л штаммами Тл 1, Тл 2, Тл 3, Тл 4, Тл 5, Тл 6

Таким образом, полученные результаты показывают характер влияния различных доз формальдегида и толуола на состав и функционирование комплекса микроорганизмов почвы, а также вскрывают механизм воздействия химических веществ (формальдегиды и толуола) на почвенную микробиоту, связанный с ее устойчивостью и проявлением токсикоза почвы.

\section{СПИСОК ЛИТЕРАТУРЫ:}

1. Стефурак В.П. Влияние техногенного загрязнения на численность и состав микробных сообществ почв. Киев, 1982. 230 с.

2. Вальков В.Ф. Системно-биологический подход при изучении почв // Научная мысль Кавказа. 1995. № 4. С. 6-10.

3. Добровольский Г.В., Никитин Е.Д. Сохранение почв как незаменимого компонента биосферы. М.: Наука, 2000. 184 с.

4. Брылов С.А., Грабчак Л.Г., Комащенко В.И. Охрана окружающей среды / под ред. С.А. Брылова и К. Штродки. М.: Высшая школа, 1985. 288 с.

5. Звягинцев Д.Г., Голимбет В.Е. Динамика микробной численности, биомассы и продуктивности микробных сообществ в почвах // Успехи микробиологии. 1983. Вып. 18. С. 215-231.

6. Круглов Ю.В. Микрофлора почвы и пестициды. M., 1991. C. 88.

7. Аржанова В.С. Миграция микроэлементов в почвах (по данным лизиметрических исследований) // Почвоведение. 1977. № 4. С. 71-77.

8. ГОСТ 28168-89. Почвы. Отбор проб. - введ. 1990.04.01. М.: Изд-во стандартов, 1989. 8 с.

9. Санитарные нормы допустимых концентраций химических веществ в почве. СанПиН 42-128-4433-87.

10. РД 52.18.608-99 Методические указания. Определение массовых долей бензола и толуола в пробах почвы. Методика выполнения измерений методом газовой хроматографии.

11. Ганжара Н.Ф., Борисов Б.А., Байбейков Р.Ф. Практикум по почвоведению. М.: Агроконсалт, 2002. 280 с.

12. Егоров Н.С. Руководство к практическим занятиям по микробиологии. М.: МГУ, 1983. 215 с.

13. Определитель актиномицетов / Г.Ф. Гаузе, Т.П. Преображенская, М.А. Свешникова и др. М.: Наука, 1983. $246 \mathrm{c}$.

14. Хоулт Дж. Определитель бактерий Берджи: в 2 т. Т. 1 / Дж. Хоулт, Н. Криг; под редакцией акад. РАН Г.А. Заварзина. 9-е изд. М.: Мир, 1997. 430 с.

15. Гаузе Г.Ф., Преображенская Т.П., Свешникова М.А., Терехов Л.П., Максимова Т.С. Определитель актиномицетов. М.: Наука, 1983. 246 с.

16. Ильина Н.А., Фуфаева Т.В., Казакова Н.А. Влияние толуола на микрофлору почвы // Фундаментальные и прикладные исследования в современном мире: Материалы IX Международной научно-практической конференции (11 марта 2015 г.) Т. 3. Санкт-Петербург: Информационный издательский учебно-научный центр «Стратегия будущего», 2015. С. 26-29.

17. Ильина Н.А., Фуфаева Т.В., Казакова Н.А. Влияние формальдегида на микрофлору почвы // Сборник научных трудов XIX Всероссийской студенческой научно-практической конференции с международным участием. 22-25 апреля 2014 г. Иркутск, 2014. C. $197-198$.

18. Гузев В.С., Левин С.В. Перспективы экологомикробиологической экспертизы состояния почв при антропогенном воздействии // Почвовед. 1991. № 9. C. 50-62.

\section{THE CHEMICALS (FORMALDEHYDE AND TOLUENE) INFLUENCE ON SOIL MICROORGANISMS OF LEACHED CHERNOZEM}

N.A. Ilyina, doctor of biological sciences, professor of the Chair of Geography and Ecology

T.V. Fufaeva, postgraduate student of the Chair of Geography and Ecology

N.A. Kazakova, candidate of biological sciences, senior lecturer of the Chair of Geography and Ecology

N.M. Kasatkina, candidate of biological sciences, associate professor of the Chair of Geography and Ecology

E.A. Vilkova, candidate of biological sciences, associate professor of the Chair of Geography and Ecology Ulyanovsk State Pedagogical University, Ulyanovsk (Russia)

Abstract. The paper assesses the status of the soil cover associated with the pollution of its waste chemical production and consumption. The authors present the data of formaldehyde and toluene influence on the abundance of actinomycetes, heterotrophic bacteria and fungi, as these groups of microorganisms provide self-purification capacity of the soil and participate in soil formation processes.

In this paper microbiological and physico-chemical methods of research are used. The study of species composition changes of some soil microorganisms groups of leached chernozem under the influence of formaldehyde and toluene showed that this factor causes changes in the complex of soil microorganisms. This factor is reflected in the decreased species richness and diversity and increase of pollution-tolerant microorganisms. 
These studies investigate a number of microorganisms that provide self-purification capacity of the soil and participate in soil formation. The results show the nature of the influence of different doses of formaldehyde and toluene on the structure and functioning of the complex of soil microorganisms, as well as reveal the mechanism of action of chemicals (formaldehyde and toluene) on soil microbiota associated with its resistance and the manifestation of toxicity of the soil.

Keywords: soil; leached chernozem; soil formation process; formaldehyde; toluene; heterotrophic bacteria; actinomycetes; fungi; soil microorganisms; xenobiotics; species richness; self-purification ability; soil formation; soil microbiota; soil toxicity; biochemical value.

\section{УДК 574.34}

\section{НЕКОТОРЫЕ СВЕДЕНИЯ О РАСПРОСТРАНЕНИИ ЕНОТОВИДНОЙ СОБАКИ НА ТЕРРИТОРИИ САМАРСКОЙ ОБЛАСТИ}

(C) 2016

Е.С. Камалова, аспирант кафедры экологии, ботаники и охраны природы

B.B. Мартынова, аспирант кафедры экологии, ботаники и охраны природы

М.Е. Фокина, кандидат биологических наук, доцент кафедры зоологии, генетики и общей экологии Самарский национальный исследовательский университет имени академика С.П. Королёва, Самара (Россия)

Аннотация. Енотовидная собака на территории Самарской области является видом-интродуцентом, который успешно освоил новую для него среду обитания. В статье приводятся данные о распространении этого вида на территории Самарской области. Исследования проводились на пойменных, степных, лесных и околоводных территориях области, в том числе в национальном парке «Самарская Лука» и Жигулевском заповеднике. Приведены сведения о наличии следов жизнедеятельности изучаемого вида в 12 муниципальных районах области (отмечены следовые дорожки, норы, временные убежища). В статье представлено GPSкартирование обнаруженных за 2002-2015 гг. нор и временных убежищ в южной части ООПТ национального парка «Самарская Лука». На данной территории были зарегистрированы 15 нор и убежищ, следовые дорожки, мочевые точки, фекалии, и дано детальное описание нор. Дальнейшее распространение популяции связано с наличием мест, пригодных для временных убежищ и нор, водоёмов, около которых енотовидные собаки могут найти себе пищу, а также меньшим влиянием фактора беспокойства (влияния человека). Полученные данные могут быть полезны для сотрудников особо охраняемых природных территорий, лесохозяйственных и охотничьих организаций для популяционного мониторинга интродуцированного вида.

Ключевые слова: енотовидная собака; Nyctereutes procyonoides; распространение; освоение территории; Самарская Лука; вид-интродуцент; поведенческая активность; адаптация; особо охраняемые природные территории; Самарская область; пойменные территории.

Введение. Енотовидная собака - вид, интродуцированный в Самарской области, поэтому необходимо изучение его влияния на аборигенные экосистемы, особенно на охраняемых природных территориях, таких как национальный парк «Самарская Лука».

В 1934 г. была осуществлена попытка акклиматизации 57 пар енотовидной собаки в Бузулукском бору. Однако по причине вспыхнувшей эпизоотии пироплазмоза, переселенные животные погибли. В 1955 г. в Куйбышевской области было выпущено 112 зверьков [1]. По мнению В.М. Шапошникова, эта попытка также окончилась неудачей: животные разбрелись, и в 60-х годах в Самарской области о них уже нет информации [2]. После подведения первых итогов акклиматизации изучение данного вида временно прекратилось, целенаправленный учет численности и оценка распространения не проводились. До сих пор не ясно, являются ли особи нынешней популяции потомками завезенных в 50-х годах енотовидных собак, или же это животные, переселившиеся из соседних областей. Лишь в 80-х гг. прошлого столетия енотовидная собака была вновь зарегистрирована в Самарской области, в литературе имеются несистематизированные данные о визуальных наблюдениях зверьков $[3 ; 4]$.

Некоторые авторы указывают на воздействие данного вида на численность охотничье-промысловых птиц, гнездящихся на земле. Уничтожая яйца и птенцов, енотовидная собака может сильно повлиять на плотность популяции дичи в местах их воспроизводства на охраняемых территориях и в охотничьих хозяйствах [5; 6]. В связи с этим енотовидную собаку считают вредителем, и в некоторых странах охота на неё разрешена круглый год.

В то же время другие исследователи отмечают, что контроль численности хищника не требуется, поскольку приносимый енотовидной собакой охотничьему хозяйству вред невелик. Енотовидная собака полифаг, в её рацион входят различные компоненты, в том числе мышевидные грызуны и насекомые. Поэтому считается, что данный хищник приносит пользу сельскому и лесному хозяйствам [7; 8; 9].

Между енотовидной собакой и такими видами, как американская и европейская норка, горностай, лесной хорь и лесная куница, лисица и барсук, выявлена трофическая конкуренция, но выражена она слабо. К примеру, рационы лисицы и енотовидной собаки не совпадают: в питании последней, кроме грызунов, большую роль играют растительные корма, беспозвоночные (моллюски и насекомые), рептилии и амфибии. Кроме того, енотовидная собака часто ищет корм вдоль берегов водоемов и на мелководьях, тогда как лисица кормится чаще на открытых территориях (полях, лугах). В местах поиска пищи енотовидная 